\title{
PRELIMINARY RESULTS OF MAPPING IN THE CRYSTAL- LINE COMPLEX AROUND RYPEFJORD AND RØDEFJORD, AND ON NORTHERN MILNE LAND, SCORESBY SUND, EAST GREENLAND
}

\author{
Niels Henriksen and A. K. Higgins
}

\section{Introduction}

The Geological Survey of Greenland (GGU) carried out in 1970 the third summer of mapping in the crystalline complex of the Scoresby Sund region. The region mapped was the continuation southwards of that mapped the previous two summers in the inner fjord zone. The main geological divisions encountered correspond generally to those already known and described briefly by Henriksen \& Higgins $(1969,1970)$.

The 1970 mapping of the crystalline complex was a team project in which eight geologists participated. Each geologist mapped about $500-600 \mathrm{~km}^{2}$ in a field season of about six weeks. While excellent exposures facilitated the work extensive use of helicopters was necessary to cover the region in the time available and some parts can only be considered as mapped to a reconnaissance standard. Topographical maps at a 1:50000 scale, enlarged from 1:200000 originals, were used for compilation of geological results and extensive use was made of oblique and vertical aerial photographs.

The geologists participating during 1970 were: B. Chadwick, Exeter; J. D. Friderichsen, Copenhagen; N. Henriksen, Copenhagen; A. K. Higgins, Copenhagen; P. Homewood, Lausanne; L. Jemelin, Lausanne; H. Rutishauser, Bern and K. Sørensen, Aarhus. The areas mapped by each geologist are shown on the key of the geological map (map 1).

This report is based on information supplied by all the geologists and many of the views presented originated from other members of the mapping team. However, the writers are responsible for the interpretations given in this paper which do not necessarily coincide exactly with those of their colleagues. In due course many of the geologists will present detailed accounts of their individual areas and GGU plans to publish 1:100 000 map sheets of the region.

\section{Previous investigations and general geology}

Prior to the GGU mapping of the region investigated (map 1) its geology was only known in broad outline. The first geologist to visit the region was Edvard Bay who produced a rough sketch map (Bay, 1895). During the 1930's H. G. Backlund and E. Wenk made a boat reconnaissance through the fjords (Backlund, 1955) and J. 


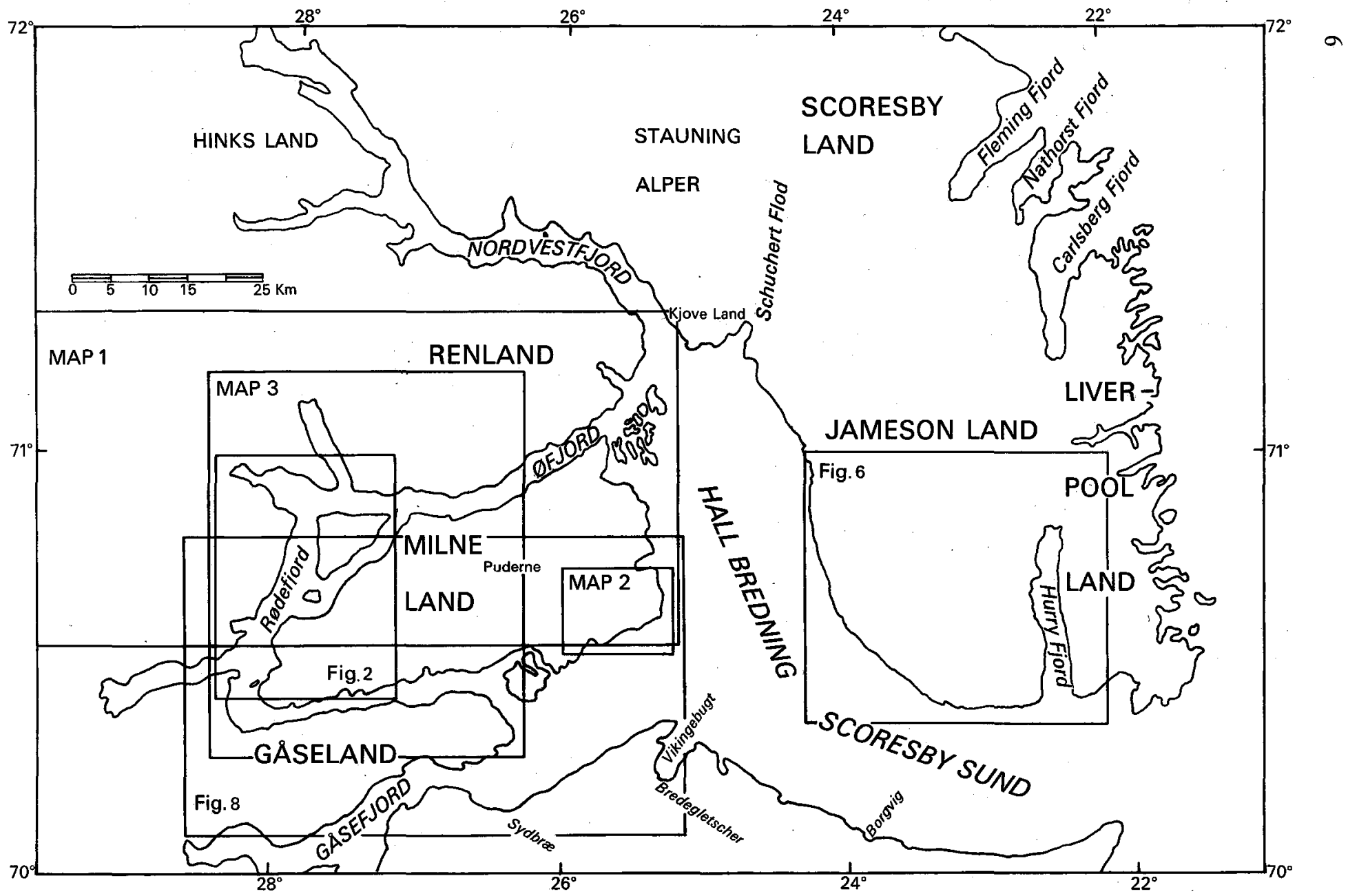

Fig. 1. Key map indicating the location of six sketch maps (maps 1-3, and figs 2,6 and 8) which accompany this report. The key map also serves as a general geographical reference map. 
Haller has visited the Eielson Gletscher area (Haller, in press). Vogt (1965) described the area lying just north of the western part of the region shown on map 1.

The geology of the region mapped by GGU in 1968 and 1969 has been described briefly by Henriksen \& Higgins $(1969,1970)$ and more detailed accounts of the Bjørneøer (Kalsbeek, 1969), south-east Renland (Chadwick, 1971) and the Charcot Land area (Steck, in press) are so far available. As already mentioned the general geological divisions described by these workers were also encountered during the 1970 mapping.

Two supracrustal sequences are distinguished in the crystalline complex of the inner Scoresby Sund region. Each rests on infracrustal rocks, considered to be basement, and cover and basement have in each case been deformed together. The two supracrustal sequences are separated from each other by thrusts and no direct age relationship can be demonstrated.

The Charcot Land supracrustal sequence comprises marbles, siliceous marbles, quartzites, semipelites, pelites and greenschists (lavas) totalling at least $2000 \mathrm{~m}$ in thickness. In the north-west corner of the Scoresby Sund region the sequence is progressively metamorphosed, stilpnomelane-bearing strata passing northwards into kyanite-bearing rocks (Steck, in press). Low grade representatives of the Charcot Land sequence outcrop in the western nunatak zone over a distance of more than $100 \mathrm{~km}$.

The Krummedal supracrustal sequence begins with siliceous schists and paragneisses with basic sills and occasional dykes, followed by a thick sequence of interbanded quartzites and mica schists, massive mica schists, and siliceous gneisses and quartzites. Lithologically there are similarities between the Krummedal sequence and the lower part of the Eleonora Bay Group (Fränkl, 1951, 1953; Haller, 1970), the lowermost deposits of the Caledonian geosyncline.

In Hinks Land, immediately north of the region shown in map 1, Krummedal supracrustal rocks rest conformably on the so-called Flyverfjord infracrustal complex, which preserves traces of orogenic activity pre-dating the deposition of the supracrustals (Vogt, 1965; Henriksen \& Higgins, 1969). The infracrustal rocks comprise mainly banded and veined gneisses with abundant amphibolite bands and ultrabasic inclusions. A conspicuous and characteristic feature is the occurrence of discordant amphibolite dykes. The Flyverfjord infracrustal complex is probably equivalent in age to the pre-Caledonian basement described by Wenk (1961) from Gåseland which has given an age of more than 2300 m.y. (Haller \& Kulp, 1962).

As it is traced eastwards the Krummedal supracrustal sequence grades into a wide zone of migmatites, the site of extensive Caledonian plutonic activity. Kalsbeek (1969) on the Bjørneøer and Chadwick (1971) in Renland distinguish two phases of migmatisation separated by intrusion of sheets and irregular bodies of intermediate rocks. The latest Caledonian plutonic rocks are post-kinematic granites (s.l.) especially concentrated in the Stauning Alper region (Haller, 1958; Henriksen and Higgins, 1970). 
Post-Caledonian sediments of Upper Palaeozoic age are preserved in a small intermontane basin on the sides of Rødefjord (Collinson, this report) and again north-east of the described region (Kempter, 1961). Mesozoic sediments rest unconformably on the Caledonian crystalline rocks of eastern Milne Land (Håkansson et $a l$, this report) and Tertiary basalts cap the summits of Milne Land and form extensive areas further south (Watt, 1970).

\section{Geological divisions}

The region mapped (map 1) can be divided along a prominent fault, following the west side of Rødefjord and Rypefjord from near Rolige Bræ in the south to Eielson Gletscher in the north, into a western zone of mainly gneisses and schists and an eastern zone of migmatites and associated plutonic rocks. A second fault in east Milne Land separates the migmatite zone from a strip of metasediments and postkinematic intrusions. Displacements on the two faults appear to have brought contrasting levels of the Caledonian fold belt into juxtaposition.

The western gneiss and schist zone includes representatives of the Krummedal supracrustal sequence and its supposed reworked infracrustal basement of amphibolite banded gneisses. These rocks lie in thrust contact above low grade chlorite phyllites probably correlateable with the Charcot Land supracrustal sequence; further outcrops of phyllites and greenschists occur on isolated nunataks in the extreme west.

The eastern migmatite zone largely comprises migmatites derived from the Krummedal supracrustal sequence, sheets of augen granite, large bodies of massive granite (s. l.) and late to post-kinematic intermediate to acid intrusions.

The metasediments of the east Milne Land fault block include mica schists, quartzites and marbles. The intrusions include a quartz syenite and various granitic bodies.

\section{The western gneiss and schist zone}

Amphibolite-banded migmatitic gneisses

Leucocratic, banded and veined migmatitic gneisses with abundant amphibolite bands and numerous ultrabasic lenses outcrop in many parts of the western gneiss and schist zone. They contrast markedly with the reddish-brown weathered supracrustals of Krummedal type which conformably overlie them. The gneisses and supracrustals have been deformed together, in some areas quite intensely, with the development of macroscopic recumbent folds. 
The lithology and stratigraphical position of the amphibolite-banded gneisses suggest correlation with the Flyverfjord infracrustal complex into which the series can be traced discontinuously northwards beyond the margin of map 1 . The occurrence around Eielson Gletscher and Rolige Bræ of discordant amphibolite dykes also found in the Flyverfjord area, reinforces such an interpretation. The dykes, of variable trend and dip, are generally $5-20 \mathrm{~m}$ thick, but where reworking has been particularly intense they cannot be distinguished from the conformable amphibolites. Further evidence of a probable basement age for the gneisses is the preservation of traces of an apparently old deformation pattern in the Eielson Gletscher area; again this pattern is lost in areas of intense Caledonian reactivation.

In the area around the head of Harefjord a homogeneous biotite augen gneiss with feldspar porphyroblasts up to $5 \mathrm{~cm}$ in diameter occurs. Its boundaries to the amphibolite-banded migmatitic gneisses are sharp, but not apparently of tectonic origin. It is thought that the augen gneisses are related to the same major plutonic event which led to the formation of the amphibolite-banded gneisses.

The amphibolite-banded migmatitic gneisses are confined to the western schist and gneiss zone with one exception, a few kilometres long strip on the east side of Rypefjord surrounded by Caledonian migmatites and granites.

\section{The Krummedal supracrustal sequence}

Red-brown weathered massive mica schists, which are often interbanded with quartzites and siliceous schists, occur throughout the western gneiss and schist zone. They can be directly correlated with the Krummedal supracrustal sequence of the the Krummedal area. The rocks outcrop over an $80 \mathrm{~km}$ wide zone ranging from Rypefjord in the east to the westernmost isolated nunataks.

As in the region to the north (Henriksen \& Higgins, 1969) a number of different lithological units can be recognised. In the nunatak zone around the upper part of Eielson Gletscher leucocratic siliceous schists and chloritic gneisses with metabasic sills and dykes occur, corresponding apparently to the lower part of the Krummedal sequence as seen in a comparable structural position in Krummedal just to the north; in both areas the leucocratic rocks are succeeded by typical red-brown schists. Similar rock types intimately folded with red-brown schists and basement gneisses occur on a large nunatak south of the Eielson Gletscher area, but where strongly deformed in this fashion distinction between the siliceous lower Krummedal sequence and rocks of the gneissic basement becomes difficult.

The most conspicuous rock types are massive garnet-kyanite schists in which the kyanites may reach $5 \mathrm{~cm}$ in length. Often units of interbanded quartzites and mica schists, mica schists with thin calcareous bands, quartzites or siliceous schists may be distinguished in the generally monotonous succession. Occasionally thin garnet-amphibolite bands occur.

In the southern part of the western gneiss and schist zone ultrabasic lenses of 
mappable dimensions are found in association with marbles in the mica schist sequence, and also in the basement gneisses. Intrusion of all the ultrabasic rocks presumably post-dated deposition of the supracrustals.

The total thickness of the mica schist succession cannot be reliably determined because of the intricate folding, but it is probably several thousand metres.

Throughout the zone the Krummedal supracrustals are migmatised to a varying degree and frequently have a somewhat gneissic aspect. They grade in many parts of the zone into garnet gneisses which are sufficiently distinctive to warrant separate description.

\section{Garnet gneisses and associated crystalline rocks}

Thick bands of pale grey, weathered, leucocratic, biotite gneisses occur in the mica schist sequence on the large nunatak in the upper part of Eielson Gletscher. More extensive areas of garnet-biotite gneisses occur around Harefjord, and north of Rolige Bræ where they have a pale rusty weathering. In both areas the gneisses are well banded and evidently are here no more than transformed parts of the Krummedal mica schist sequence.

North of Harefjord the gneisses become more migmatitic westwards but usually comprise finely banded gneisses with occasional amphibolite and calc-silicate bands. Kyanite is widespread in certain bands and garnet porphyroblasts are also abundant locally. On the west side of Rypefjord there is a gradation into kyanite-garnet-mica schists.

At Rolige Bræ the gneisses may be siliceous with amphibolite lenses or banded garnet-rich rocks with scattered marble bands locally up to $50 \mathrm{~m}$ thick. Again the degree of migmatisation increases towards the west and granitic neosome material dominates the outcrops in a row of small nunataks.

Garnet gneisses with amphibolite and quartz gneiss bands of mappable dimensions occur south of Harefjord and on Proppen capping a thick sequence of mica schists. Here the gneiss-mica schist contact appears to be a thrust.

Low grade metamorphic rocks in the nunatak zone

On the isolated nunataks of the Royston Nunatakker in the north-west of the region occur massive metavolcanic greenstones which have been described previously as part of the Charcot Land supracrustal sequence (Henriksen \& Higgins, 1969). About $15 \mathrm{~km}$ further south low grade chlorite phyllites are found on two nunataks and while not identical to known Charcot Land sequence rock types these probably belong to the same succession.

Chlorite phyllites also occur in tectonic windows beneath high grade basement gneiss and mica schist around the upper part of Eielson Gletscher. These phyllites are associated with siliceous dolomites, calcareous phyllites and siliceous schists, 
rock types known from the Charcot Land sequence in Charcot Land. These rocks overlie conformably homogeneous chloritic granites and siliceous chloritic gneiss which conceivably may be equivalents of the basement to the Charcot Land sequence (cf. Steck, in press).

A small occurrence of banded iron-bearing quartzite with associated pelites in the Eielson Gletscher area, and siliceous marbles and green chloritic phyllites on a nunatak in the extreme south-west of the mapped region, are most likely also representatives of the same belt of low grade metamorphic rocks.

\section{The eastern zone of migmatites and associated plutonic rocks}

\section{Migmatitic gneisses}

Migmatised pelitic and quartzitic gneisses are found throughout the eastern migmatite zone, although the intensity of migmatisation varies from place to place. In the pelitic migmatites the quartzo-feldspathic neosome usually dominates over the paleosome, but some quartzitic gneisses survive locally as relatively non-migmatised units. Garnet is ubiquitous and sillimanite a common metamorphic mineral.

In east Renland Chadwick (1971) has distinguished two migmatitic phases. The early phase is synkinematic and separated from the late-stage migmatisation by intrusion of monzonitic sheets and irregular bodies. The late-stage migmatisation has also been distinguished in north-east Milne Land, but is more difficult to recognise because of the scarcity of intermediate intrusions.

Well-banded migmatitic gneisses in north-east Milne Land contain frequent conformable granitic bands. Over wide areas granitisation has been so intense that the common rock type of certain levels is essentially a granite with abundant orientated gneiss and quartzite lenses. The only significant supracrustal marker horizons to survive are banded marbles and a very pure characteristically banded quartzite; both rock types form bands several hundred metres thick.

On the west side of Rypefjord occurs a small area of nebulitic migmatite of a distinctive red weathering colour. It has a medium-grained granitic neosome and is conspicuously rich in garnet. Mafic to ultrabasic garnet-biotite sills are common. Towards the north-west the migmatite becomes banded and grades into Krummedal-type mica schist.

In the southern part of the migmatite zone amphibolite bands and lenses, rare and insignificant elsewhere, become increasingly important constituents of the paleosome. It is uncertain whether this is indicative of lithological variation in the Krummedal supracrustal sequence which is considered to make up the dominant proportion of the paleosome, or whether other lithological units have been here involved in the Caledonian migmatisation. 
Augen granites

Extensive sheets and massive bodies of garnet augen granite occur around inner Øfjord. The sheets, which may exceed $1000 \mathrm{~m}$ in thickness, are in general concordant to but in detail often cut the foliation of the surrounding gneiss; large gneissic xenoliths are not uncommon.

The feldspar augen, sometimes single rectangular crystals up to $10 \mathrm{~cm}$ across, but usually aggregates of microcline crystals, are in many bodies deformed and strongly lineated. The rocks as a whole are often well foliated and of gneissic texture, but their chemical composition (Chadwick, 1971) is granitic (s.s.).

The augen granites are normally garnet-biotite rocks with occasionally a little sillimanite but there are several varieties. Whereas most sheets are homogeneous and lack banding, a more melanocratic phase with a flaser structure occurs at the margins of some sheets. In some bodies elongate microcline augen are particularly abundant, and in others garnet is the only mafic mineral in an otherwise leucocratic granite. Two of the large bodies comprise in part a coarse-grained homogeneous garnet granite, similar in type to some of the massive granites on Storø and at the head of Rypefjord.

The augen granites are clearly intrusive, and probably were emplaced in close relationship to the first migmatisation stage. Chadwick (1971) suggests they were intruded into a pile of more or less horizontal metasediments at a deep orogenic level. The foliation and augen orientation developed more or less parallel to the sheet boundaries, and was subsequently influenced by the major isoclinal recumbent folding. A later phase of folding refolds the foliation in the granites.

Lamprophyre dykes are relatively common in some parts of these granites; they may be discordant to the foliation and may be folded.

\section{Granitic rocks on Storø and around Rypefjord}

Large areas of medium to coarse-grained biotite granite occur on Storø and northeast of the head of Rypefjord. Enclaves and schlieren of gneissic material are common and their boundaries with the surrounding rocks are usually transitional. Garnet is commonly found.

The body north-east of Rypefjord contains marble and folded quartzite bands of mappable size whose preferential preservation may be indicative of autochthonous granitisation. This granite also encloses an enclave of augen granite. A sill-shaped intermediate intrusion cuts the northern part of the granite; it may be of comparable age to the monzonites of eastern Renland.

\section{Diorites}

Dark grey-green weathered massive dioritic rocks have been noted as sills in the migmatites on both sides of central Øfjord, in north-east Milne Land and at the head 
of Rypefjord, and irregular shaped bodies occur on the east side of Snesund. They appear to be very similar to the intermediate rocks described from eastern Renland (Chadwick, 1971) and the Bjørneøer (Kalsbeek, 1969).

The diorite sheets often preserve a magmatic texture and chilled margins have occasionally been noted. While generally conformable they cut in places mesoscopic folds in the migmatites, but may themselves be cut by scattered pegmatitic and granitic veins.

The observations made during 1970 support generally the view of Chadwick (1971) that the diorites were emplaced later than the first, and main, phase of migmatisation and deformation.

\section{Post-kinematic granites}

A series of thick granitic sheets of varying type cap the mountains of northern Milne Land. While the sheet-form is characteristic there are many clearly discordant contacts where the sheet boundaries transect all the structures in the migmatites. Occasional strips of inclusions may be noted but they are an uncommon feature.

One of the main granite types is a rather mafic biotite-rich granite, coarse-grained to pegmatitic with characteristic large pink feldspars. This is cut locally by numerous veins emanating from a later leucocratic granite sheet. The leucocratic body has a creamy weathering colour, is medium to coarse-grained and sometimes porphyritic. Both varieties occur in sheets up to $300 \mathrm{~m}$ thick.

In a deeply dissected glacier valley in eastern Milne Land a third variety of granite has been noted. In this medium-grained generally leucocratic body the mafics present are concentrated into conspicuous clusters scattered evenly through the body.

\section{The east Milne Land fault block}

East Milne Land east of a NNE-SSW trending fault line comprises well-preserved areas of assumed Caledonian metasediments bounded by a variety of post-kinematic intrusions. Mesozoic sediments resting on a peneplained surface of these crystalline rocks cross the fault-line without displacement. Outliers of Tertiary plateau basalts rest on the Mesozoic rocks locally.

\section{Metasediments}

The metasedimentary rocks include quartzites, mica quartzites, mica schists and marbles. The main outcrops occur in the north where numerous quartzite units of mappable dimensions have been distinguished and a marble $150 \mathrm{~m}$ thick occurs. Further small outcrops occur in the southern part of the area adjacent to the fault line. 
The sediments are extremely well banded and ripple marks and cross-bedding are preserved; the latter have been used to establish the way-up of the sequence locally.

The common mineral paragenesis in the mica schists is sillimanite-cordieritebiotite-muscovite-quartz, and in the quartzites biotite-muscovite-quartz.

Two major folds, an anticline and a syncline, occur in the north of the area, both with steep NE-plunging axes. However, the most conspicuous folds encountered in the field are a later set of minor flat-lying structures with gently plunging $E$ to $S E$ trending fold axes.

The isolation of the Milne Land metasedimentary sequence from other Caledonian sedimentary sequences makes correlation very difficult. It is comparable in some respects to parts of the Krummedal supracrustal sequence but its true stratigraphical position is at present uncertain.

\section{Post-kinematic intrusions}

The earliest and most extensive of the several varieties of intrusions is a granodiorite body, perhaps an extremely thick sheet-formed body. At both north and south margins the granodiorite is bordered by a marble. The bulk of the body is mesocratic and medium-grained and notable for the occurrence of regularly distributed more mafic inclusions of igneous origin. Very locally the inclusions are concentrated into zones, and particularly along the north margin of the intrusion they are flattened and foliated parallel to the margin. Locally there appear to be more mafic and more leucocratic phases in the granodiorite, but as a whole it is remarkably uniform.

A coarse-grained to porphyritic quartz syenite body cuts across the sediments and has an irregular but well exposed contact with the granodiorite. A wide outer zone is rather mafic, rich in biotite and amphibole, and the central part is notably leucocratic and porphyritic. In the contact between the two zones complex textural variations are seen.

There are two different types of granites. The one type in the north of the area is a medium-grained, leucocratic, biotite granite with typical intrusive contacts, and is comparable in most respects to many of the major granite plutons of the Stauning Alper (Henriksen \& Higgins, 1969). The second type occurring in the south of the area occurs mainly as small circular plugs punching up through the granodiorite. They are pinkish fine to medium-grained granites.

\section{Structures}

Several phases of Caledonian folding, thrusts and faults can be distinguished in the region. Traces of one or two phases of pre-Caledonian deformation can be found locally in the infracrustal basement complexes but usually these are obscured by the intensity of the Caledonian overprinting. 
The most important and probably the earliest of the Caledonian structures are major recumbent folds found throughout the region. In the Eielson Gletscher area and again near Rolige Bræ basement amphibolitic gneisses form the cores of tight recumbent folds with an envelope of mica schists. Recumbent folds are widespread in the mica schist sequence as a whole. A prominent isoclinal example deforms garnet gneisses, amphibolite and quartzite south of the head of Harefjord.

In the eastern migmatite zone major recumbent folds with limbs traceable for $5 \mathrm{~km}$ or more occur in Renland and Milne Land. In central Milne Land sequences of major isoclinal folds can be distinguished in certain sections where distinctive horizons such as rust bands occur. It seems probable they are present but undetected in other sections and estimations of thickness of the migmatitic gneisses in the region are subject to great error.

The axes of the recumbent structures trend usually E-W to NE-SW; an E-W lineation with a shallow plunge appears to be related to the formation of these folds. The lineation in the migmatite zone is seen in the common elongation of feldspar augen in the augen granite and the orientation of sillimanite. It is commonly seen in much of the western schist and gneiss zone as a biotite, amphibole or kyanite lineation.

A second set of E-W to NE-SW trending folds but with steeply dipping axial planes is found in many areas. They are common in the northern part of the western schist and gneiss zone and in south-west Renland. In the migmatite zone major examples deform the augen granite sheets. West of Rypefjord, on Milne Land and in Renland open to tight examples are seen to refold the earlier recumbent structures, and on a mesoscopic scale the mineral lineation is deformed.

A late phase of N-S trending open folding or gentle warping on widely spaced vertical axial planes is superimposed on the earlier structures. This occurs in most parts of the region.

Of interest is the general correlation of the sequence of deformation in the western gneiss and schist zone and the eastern migmatite zone. E-W trending structures occur also in the Milne Land fault block but the N-S folds have not been noted. The pattern of deformation as presented here is over-simplified but serves to emphasise the marked structural similarity between the different zones representing contrasting levels of the orogenic belt.

In the area west of the fjord zone flat-lying thrusts are characteristic; they often separate rocks of distinct lithological and metamorphic character. At the head of Harefjord a prominent thrust separates basement and cover, and in the upper Eielson Gletscher area a thrust occurs between low grade metamorphic rocks comparable to the Charcot Land sequence, and Krummedal sequence mica schists and amphibolite gneisses. Several parallel major and minor thrusts occur in the upper Eielson Gletscher area and outline two tectonic windows lying on the same N-S trending culmination zone running through Krummedal itself. 
The thrusts evidently post-date metamorphism and the main deformation phase. They may however have been affected by the later gentle warping on N-S trending axes.

Normal faults mainly of N-S to NNE-SSW trend occur throughout the area. Chadwick (1971) has estimated the cumulative downthrow of a number of minor faults in Renland at 1000-1500 m eastwards. The east Milne Land fault has a presumed eastward downthrow and forms the continuation of part of the major fault system bordering the east side of the Stauning Alper. A series of faults with a westerly downthrow seen in south-west Renland suggest that the migmatite zone as a whole may have a horst-like structure.

The most prominent fault in the inner fjord zone is that bordering the east side of the Rødeø conglomerate which divides also the western migmatite zone from the eastern gneiss and schist zone. The principal movement is westwards, but the conglomerate itself is downthrown eastwards. Traced northwards the continuation of the fault probably joins up with the prominent fault or low angle thrust which crosses the T-sø area north of Nordvestfjord (Henriksen \& Higgins, 1969).

Other N-S faults are found in the nunatak zone where they displace the thrusts, and minor E-W faults occur on Storø.

Scattered plug-like intrusive breccias occur on Renland and Milne Land and are most likely of Tertiary age (Chadwick, 1971). Other signs of Tertiary activity are seen in the N-S trending dyke swarm in the nunatak zone and scattered dykes around Storø.

\section{Concluding remarks}

The most conspicuous feature of the region mapped during 1970 is its division by major faults into distinct and contrasting zones considered to represent different levels of the Caledonian orogenic belt. Plutonism is notably concentrated in the eastern migmatite zone and the east Milne Land fault block.

In general the same geological divisions were encountered as in previous years. The Krummedal supracrustal sequence was traced more or less continuously southwards resting on a crystalline supposed basement. A new feature is the occurrence of amphibolite and ultrabasic lenses in the mica schists in the southern part of the region near Rolige Bræ. Low grade metamorphic rocks in the outermost western nunataks are the probable continuation of the Charcot Land supracrustal sequence.

The eastern migmatite zone seems largely to have been formed by the migmatisation and granitisation of rocks of the Krummedal supracrustal sequence, as was also the impression gained from the earlier investigations of the region to the north. Locally strips of marbles and quartzites have survived as mappable bands. In the 
southern part of the migmatite zone the occurrence of amphibolite in the paleosome raises the question of whether elements of basement are incorporated, but it may be that their presence reflects rather the occurrence of amphibolite in the now transformed Krummedal supracrustal sequence.

In east Milne Land the well-preserved metasediments are a new and interesting feature. They cannot be simply correlated with other known occurrences of Caledonian supracrustal rocks, although there are many similarities. The series of postkinematic plutons can probably best be regarded as a continuation of the zone of plutons in the Stauning Alper.

Excluding the low grade rocks in the extreme west the metamorphic minerals have in general a simple distribution: kyanite in the western gneiss and schist zone, sillimanite in the migmatite zone, and sillimanite and cordierite in the east Milne Land metasediments. Garnet occurs everywhere.

Despite the contrast in rock types from area to area the pattern of deformation seems to be much the same throughout the region. A phase of recumbent folding accompanying the main migmatisation was succeeded by open to tight east-west folding and later gentle north-south warping. There is evidence of variation in this perhaps over-simplified pattern in individual areas but the similarity between different parts of the region is nevertheless marked.

In the nunatak region major thrust planes have again been encountered as in the region to the north (Vogt, 1965; Henriksen \& Higgins, 1969; Steck, in press) and in Gåseland to the south (Wenk, 1961). They reinforce the impression that this is the border zone of the Caledonian fold belt.

\section{References}

[Backlund, H. G.] 1955: Helge Backlund's travels. In Koch, L. Report on the expedition to central East Greenland 1926-39. Conducted by Lauge Koch. Part II. Meddr Gronland 143, 2, 303-361.

Bay, E. 1895: Geologi. In Ryder, C. Den østgrønlandske Expedition, udført i Aarene 1891-92 under Ledelse af C. Ryder. Meddr Granland 19, 145-187.

Chadwick, B. 1971: Preliminary account of the geology of south-east Renland, Scoresby Sund, East Greenland. Rapp. Gronlands geol. Unders. 34, $32 \mathrm{pp.}$

Fränkl, E. 1951: Die untere Eleonora Bay Formation in Alpefjord. Meddr Grønland 151, 6, 15 pp.

Fränkl, E. 1953: Die geologische Karte von Nord-Scoresby Land (NE-Grønland). Meddr Grønland 113, $6,56 \mathrm{pp}$.

Haller, J. 1958: Der "Zentrale Metamorphe Komplex" von NE-Grönland. Teil II. Die geologische Karte den Stauning Alper und des Forsblads Fjordes. Meddr Grønland 154, 3, 153 pp.

Haller, J. 1970: Tectonic map of East Greenland (1:500 000). An account of tectonism, plutonism and volcanism in East Greenland. Meddr Gronland 171, 5, 286 pp.

Haller, J. in press: Geology of the East Greenland Caledonides. London: John Wiley. 374 pp.

Haller, J. \& Kulp, J. L. 1962: Absolute age determinations in East Greenland. Meddr Gronland 171, 1, 77 pp.

Henriksen, N. \& Higgins, A. K. 1969: Preliminary results of mapping in the crystalline complex around Nordvestfjord, Scoresby Sund, East Greenland. Rapp. Gronlands geol. Unders. 21, 5-20. 
Henriksen, N. \& Higgins, A. K. 1970: Preliminary results of mapping in the crystalline complex of Renland, the southern Stauning Alper and south-west Liverpool Land, Scoresby Sund, East Greenland.

Rapp. Grønlands geol. Unders. 30, 5-16.

Kalsbeek, F. 1969: Preliminary report on the geology of Bjørneøer, Scoresby Sund. Rapp. Grønlands geol. Unders. 26, $33 \mathrm{pp}$.

Kempter, E. 1961: Die jungpaläozoischen Sedimente von Süd Scoresby Land. Meddr Grønland 164, 1, $123 \mathrm{pp}$.

Steck, A. in press: Kaledonische Metamorphose der praekambrischen Charcot Land Serie, Scoresby Sund, Ost-Grönland. Bull. Gronlands geol. Unders. (also Meddr Grønland 192, 3).

Vogt, P. 1965: Zur Geologie von Südwest Hinks Land (Ostgrönland $71^{\circ} 30^{\prime}$ N). Meddr Grønland 154, 5,24 pp.

Watt, W. S. 1970: Preliminary report of the mapping of the basalt area, south Scoresby Sund. Rapp. Grønlands geol. Unders. 30, 30-37.

Wenk, E. 1961: On the crystalline basement and the basal part of the pre-Cambrian Eleonora Bay Group in the southwestern part of Scoresby Sund. Meddr Grønland 168, 1, 54 pp.

\title{
OBSERVATIONS ON THE FIELD RELATIONSHIPS AND CHARACTERISTICS OF THE RØDEØ CONGLOMERATE OF INNER SCORESBY SUND, EAST GREENLAND
}

\author{
(with notes on the Lower Permian sediments of the Schuchert \\ Flod area)
}

\section{J. D. Collinson}

\section{Introduction}

In the summer of 1970 , four weeks were spent in mapping and making sedimentological observations in the red conglomerates and sandstones (the Rødeø Conglomerate) of Rødefjord and Rypefjord area. A period of ten days was also spent looking at the Permian and (?) Carboniferous sediments of the Schuchert Flod area for comparative purposes. The fieldwork was carried out with the assistence of C. Bülow. The Rødeø Conglomerate had previously been briefly described by Bütler (1957, 1961) and the Schuchert Flod sequence in more detail by Kempter (1961).

\section{Rodeø Conglomerate}

Age of sediments

The sediments overlie the migmatites and granites of C. Hofmann Halvø and Storø with nonconformity and are intruded by dykes of presumed Tertiary age. They lack any diagnostic fossils. The only organic remains were badly preserved plant casts 